PEMBELAJAR: Jurnal Ilmu Pendidikan, Keguruan, dan Pembelajaran

Volume 1 Nomor 2 Oktober 2017 Hal. 75 - 84

e-ISSN: 2549-9114 dan p-ISSN: 2549-9203

(Received: Agustus-2017; Reviewed: September-2017; Published: Oktober 2017)

\title{
DINAMIKA PSIKOLOGIS KELUARGA POLIGAMI PENYANDANG TUNA NETRA
}

\author{
Ainulhusnah Pascayani \\ Fak. Psikologi, Universitas Negeri Makassar \\ Corresponding Email: lotus04_17778@ yahoo.co.id
}

\begin{abstract}
Abstrack: This research was held to find out the dynamics of psychological subject in polygamy, the way of handle the family, and the interaction of another family member, the research method is qualitative research by using study case approach through deep interview and observation during the interview, the subject of the research is the main subject it is husband, for another subjects are first wife, second wife, third wife, and forth wife, and one of the children from the main subject, the research result shows that there is psychological dynamic in her polygamy life and her family, the are, positive impact and negative impact, from the positive impact like protect and help the old women but not yet marriage and the woman who have criminal problem like harassment in their family, stay away from something not good in religion, and can built a good relationship, the wife have a partner in working and care together to the husband, and feel free when they don't have time, the other ones, there is a negative impact, there are there is a jealousy between the wife and the polygamy, the is negative thinking in social life, the way of subject care the family, by teaching religious point to all the member of family, the interaction of family member held by meet together, built a relationship, care each others, protect, and keep to all the member of family, the subject is blind person but he has a good personality to all people so that's why many woman love her.
\end{abstract}

Keywords: Family, Polygamy, Blind Person

\begin{abstract}
Abstrak: Penelitian ini dilakukan untuk mengetahui dinamika psikologis subjek dalam berpoligami, cara membina keluarga, dan interaksi antar anggota keluarga lainnya. Metode penelitian yang digunakan adalah penelitian kualitatif dengan menggunakan pendekatan studi kasus melalui wawancara mendalam dan observasi selama wawancara. Adapun subjek dalam penelitian ini adalah subjek utama yaitu suami, kemudian subjek lainnya yaitu istri pertama, kedua, ketiga, keempat, dan salah seorang anak dari istri subjek utama. Hasil penelitian menunjukkan bahwa terdapat dinamika psikologis dalam kehidupan poligami subjek dan keluarganya, berupa dampak positif dan dampak negatif, yaitu dari dampak positif seperti melindungi dan menolong perempuan-perempuan yang sudah berumur namun belum menikah dan yang mengalami kekerasan dalam rumah tangga, terhindar dari perbuatan maksiat dan zina, kemudian dapat terjalinnya tali silaturahmi, istri memiliki teman dalam bekerja sama mengurus suami, dan merasa bebas jika tidak mendapat jatah bergilir. Selain itu, adapun dampak negatifnya, yaitu terjadi kecemburuan diantara para istri dan pelaku poligami dianggap buruk dalam masyarakat. Cara subjek utama membina keluarganya, yaitu dengan menerapkan ajaran agama kepada semua istri-istri dan anak-anaknya. Interaksi antar anggota keluarga lainnya, dilakukan dengan cara berkumpul bersama dalam sebuah acara, mempererat tali silaturahmi, saling perhatian, melindungi, dan menjaga diantara anggota keluarga lainnya. Subjek adalah seorang penyandang tuna netra, namun subjek memiliki pribadi yang baik dan ramah kepada siapa saja, sehingga banyak perempuan yang menyukainya.
\end{abstract}

Kata kunci: Keluarga, Poligami, Tuna Netra

(C2017 -Pembelajar Universitas Negeri Makassar. Ini adalah artikel dengan akses terbuka dibawah lisensi CC BY-NC-4.0 (https://creativecommons.org/licenses/by-nc/4.0/ ). 


\section{PENDAHULUAN}

Poligami adalah masalah yang selalu menjadi kontroversi di Indonesia. Beragam kasus poligami yang terjadi berupa kasus yang mendapat persetujuan dari istri sebelumnya dan juga kasus poligami yang tidak mendapat persetujuan dari istri sebelumnya. Kasus poligami, baik yang mendapat persetujuan ataupun tidak mendapat persetujuan dari istri, selalu menjadi perbincangan dikalangan masyarakat.

Poligami memang terdapat dalam agama Islam, agama yang dipeluk oleh sebagian besar penduduk Indonesia, namun pemahaman orang Islam terhadap poligami dalam ajaran agama berbeda-beda. Ada yang beranggapan bahwa poligami dianjurkan dalam keadaan tertentu, misalnya menolong saudari-saudari seiman yang sudah menua namun belum menikah dan janda. Ada juga yang percaya bahwa poligami seharusnya ditinggalkan, dikarenakan poligami dianggap dapat merusak kehidupan keluarga sebelumnya (Dickson, 2007).

Kasus-kasus poligami yang terjadi di Indonesia, diantaranya yaitu di akhir tahun 2001 muncul Puspo Wardoyo, seorang pengusaha yang memiliki sejumlah rumah makan Ayam Bakar Wong Solo di berbagai kota besar di Indonesia dan mengaku sukses melakukan poligami dengan empat orang istri. Kasus yang sama juga dialami oleh seorang $D a^{\prime} i$ kondang Aa Gymnastiar mengenai perkawinan poligaminya di tahun 2006 yang menimbulkan kecaman dari kaum ibu-ibu. Kontroversi perkawinan poligami yang dilakukan pengusaha kaya Syekh Puji, kepada anak dibawah umur, juga tidak luput dari perhatian masyarakat umum (Hariyanti, 2008).

Kasus poligami yang ada di atas, menimbulkan pro dan kontra di Indonesia, khususnya dalam kalangan masyarakat. Misalnya, Puspo Wardoyo merupakan seorang pengusaha sukses yang memiliki beberapa usaha rumah makan dan mampu berpoligami, baik itu secara materi, spiritual, maupun yang lainnya, sehingga dapat membawa kebahagiaan dan keberuntungan. Kemudian, seorang $D a^{\prime} i$ kondang Aa Gymnastiar melakukan poligami dan mendapat kecaman dari kaum ibu-ibu dan Syekh Puji yang juga melakukan poligami kepada anak dibawah umur, namun kedua tokoh poligami tersebut dapat menjalani kehidupan poligami bersama istri-istrinya dengan lancar dan bahagia meskipun mendapat sorotan dari masyarakat.
Di Makassar, Lembaga Bantuan Hukum Asosiasi Perempuan Indonesia untuk keadilan (LBH APIK) setiap tahun menerima 50 sampai 70 laporan kasus kekerasan dalam rumah tangga (KDRT) oleh kaum perempuan. Sekitar 10\% nya berasal dari kasus poligami. Hal itu disebabkan kaum perempuan yang melaporkan kasus poligami dan umumnya karena sang suami menikah lagi tanpa sepengetahuan atau persetujuan dari sang istri (Burhani, 2006, 6 Desember).

Berdasarkan kasus-kasus poligami yang ada di atas, dapat disimpulkan bahwa poligami terbukti mendapat respon pro dan kontra dalam masyarakat, baik yang mendapat persetujuan maupun yang tidak mendapat persetujuan dari istri pertama. Kasus poligami yang ada di Indonesia, tidak selamanya menimbulkan dampak negatif dalam keluarganya, namun ada pula keluarga poligami yang justru hidup rukun dan bahagia bersama. Seorang suami yang memiliki fisik normal saja dapat menjalani kehidupan poligami bersama beberapa istrinya dengan rukun, lain halnya juga dengan seorang suami yang memiliki keterbatasan fisik namun mampu menjalani kehidupan poligaminya dengan baik, rukun, dan bahagia bersama istriistrinya.

Seseorang dengan kondisi fisik yang normal dan memiliki kemampuan materi yang cukup, terkadang merasa kesulitan untuk berlaku adil kepada istri-istrinya. Hal tersebut yang menjadi salah satu pertimbangan bagi seseorang untuk berpoligami. Kenyataannya, tidak hanya orang dengan kondisi fisik yang normal dan kemampuan ekonomi yang baik saja yang dapat melakukan poligami, namun seseorang dengan keterbatasan fisik dan ekonomi menengah ke bawah juga dapat melakukan poligami.

Peneliti menemukan kasus poligami yang dilakukan oleh seorang pria penyandang tuna netra yang juga memiliki empat orang istri dalam satu atap. Subjek menikahi istri kedua dan istri ketiga atas saran dan inisiatif istri pertama subjek. Istri kedua subjek merupakan kenalan subjek yang tidak sengaja ditemuinya ketika anak subjek dirawat di rumah sakit, sedangkan istri ketiga subjek merupakan kerabat dari istri pertama. Hal tersebut dapat ditunjukkan dari hasil wawancara peneliti dengan subjek saat melakukan pilot studi yang menyatakan bahwa subjek memutuskan untuk berpoligami atas dasar permintaan dari istri pertama subjek. 
"saya menikah dengan istri kedua dan ketiga itu karena istri pertamaku yang suruh saya menikah lagi. Dia bilang sama saya, kalo dia ndak marahji seandainya saya menikah lagi dan justru dia katanya mau potong kambing kalo saya menikah lagi, ndak tahu kenapa dia begitu...” (wwcr2/20-9-2012).

Berdasarkan hasil wawancara yang dilakukan peneliti pada saat pilot studi, diperoleh informasi bahwa pernikahan subjek dengan istri kedua dan ketiga, ternyata merupakan inisiatif dari istri pertama subjek. Istri pertama yang meminta agar subjek mau menikah dengan perempuan-perempuan yang sekarang dijadikan istri kedua dan ketiga. Istri keempat meminta subjek untuk menikahinya, walaupun pada awalnya keluarga dari istri keempat tidak merestui pernikahannya.

Seseorang yang memiliki keterbatasan dalam hal penglihatan (tuna netra), biasanya dihubungkan dengan kurangnya kepercayaan diri dan interaksi dengan orang-orang normal yang dapat melihat. Hal ini juga memiliki keterkaitan dengan sikap orang-orang normal yang dapat melihat terhadap orang yang memiliki keterbatasan dalam penglihatan (Muharani, Hartati, \& Dewi, 2009). Fakta di lapangan, menunjukkan bahwa tidak hanya orang normal saja yang mampu berinteraksi dengan baik, namun seseorang yang memiliki keterbatasan fisik juga mampu berinteraksi dengan orang lain dan lingkungannya. Penyandang tuna netra juga mampu membentuk sebuah keluarga melalui hasil interaksinya dengan orang lain, bahkan ada diantara para penyandang tuna netra yang juga mampu berpoligami. Hasil pilot studi yang dilakukan peneliti memberikan sebuah fakta, bahwa seorang penyandang tuna netra mampu memiliki empat orang istri sekaligus. Berikut hasil wawancara yang dilakukan peneliti pada saat melakukan pilot studi.

"istri pertamaku itu orang jawa, trus istri kedua orang bogor, baru istri ketigaku orang jombang, ee..yang terakhir ini orang jeneponto..." (wwcr2/20-9-2012).

Selain itu, adapun alasan yang mendasari para istri subjek bersedia untuk dipoligami, yaitu istri pertama bersedia untuk dipoligami karena merasa dirinya sudah tua dan tidak dapat lagi memenuhi kewajibannya sebagai seorang istri untuk suaminya. Alasan istri kedua, dikarenakan merasa diguna-guna oleh istri pertama subjek. Lain halnya dengan alasan istri ketiga, dikarenakan merasa ada yang bersedia untuk bertanggung jawab terhadap diri dan anak-anaknya. Kemudian, alasan istri keempat bersedia untuk dipoligami, karena kejujuran subjek pada istri keempat mengenai kondisi diri dan keluarga sebelumnya, seperti ketiga istri dan anak-anaknya.

"Ee...karena saya sudah tua terus
sudah ndak kuat lagi..."
(wwcr5/S4/090113).
"Yaa...mungkin karena saya
kapincut mah istilahnya..."
(wwcr4/S3/291212).
"...hanya ada yang mau
tanggung jawab sama saya sama
anak-anak". (wwcr3/S2/281212).
"Iya, karena dia terus terang,
jujurki bilang saya sudah punya 3
orang istri sama anak juga,
begitu. Tidak bisa mi toh juga
cari yang lain, takkala' disukami
baru jujur sekali sama saya".
(wwcr6/S5/250213).

Dinamika-dinamika yang terjadi pada keluarga subjek dalam hal ini seseorang penyandang tuna netra dengan empat orang istri, memberikan ketertarikan pada peneliti untuk melakukan penelitian lebih lanjut, berupa dinamika psikologis keluarga poligami penyandang tuna netra. Sehingga diharapkan dapat memberikan informasi bagi keluarga poligami, bahwa dalam membina keluarga dengan baik akan terwujudnya keharmonisan, maka menjalani kehidupan poligami tidak selamanya bersifat negatif, namun jika dijalani dengan sesuai aturan maka dapat bersifat positif.

\section{Poligami}

Setiyaji (2006) mengemukakan bahwa dalam antropologi sosial, poligami adalah suatu praktik pernikahan kepada lebih dari satu suami atau istri (sesuai dengan jenis kelamin orang bersangkutan) sekaligus pada waktu yang bersamaan (berlawanan dengan monogami, yang mana seseorang memiliki hanya satu suami atau istri pada suatu saat). Terdapat tiga bentuk poligami, yaitu : 
1. Poligini (seorang pria memiliki beberapa istri sekaligus),

2. Poliandri (seorang wanita memiliki beberapa suami sekaligus), dan

3. Pernikahan kelompok (bahasa inggris: group marriage, yaitu kombinasi poligini dan poliandri).

Secara etimologis, istilah poligami berasal dari Bahasa Yunani, yaitu apolus yang berarti banyak dan gamos yang berarti perkawinan. Kata lain yang mirip dengan poligami adalah poligini. Poligini juga berasal dari bahasa Yunani, yaitu polus yang berarti banyak dan gene artinya perempuan (Nurohmah, 2003). Hal yang sama juga dipaparkan oleh Abdullah (Susanti, Mufattahah, \& Zulkaida, 2004) mengemukakan bahwa kata poligami berasal dari Yunani polygamie, yaitu poly berarti banyak dan gamie berarti laki-laki, jadi arti dari poligami adalah laki-laki yang beristri lebih dari satu orang wanita dalam satu ikatan perkawinan. Seperti seorang suami mungkin mempunyai dua istri atau lebih pada saat yang sama. Santoso (Kamus Pintar Bahasa Indonesia, 1996) bahwa pengertian poligami adalah laki-laki yang beristri lebih dari satu orang.

\section{Alasan Suami Melakukan Poligami dan Alasan Istri Menerima Suaminya Berpoligami}

As Sadr (2003) mengemukakan bahwa ada beberapa pembenaran pernikahan poligami yang dimaksudkan dalam Islam, yaitu:

a. Seorang istri yang tidak mampu melahirkan keturunan, sehingga suami harus memilih antara menerima keluarga tanpa anak atau menikahi perempuan lain yang mampu memberikan keturunan.

b. Kaum perempuan memiliki jumlah lebih banyak daripada kaum laki-laki.

c. Merasa kasihan terhadap janda dan perempuan-perempuan yang sudah menua, namun belum menikah.

d. Seorang istri yang menderita cacat fisik atau mental dan tidak dapat melakukan tugastugasnya sebagai istri, merespon keinginan suami, atau memberikan perhatian kepada anggota keluarga lainnya.

e. Sebagian laki-laki memiliki energi seksual yang tinggi, sehingga membutuhkan penyaluran yang tepat.

\section{Bentuk Keadilan dalam Pernikahan Poligami}

Chodjim (2007) mengemukakan bahwa poligami secara agama diatur dalam Al-Qur'an surah An-Nisa ayat 3. Terjemahan dari ayat tersebut dapat dilihat dalam terjemahan AlQur'an yang membahas tentang poligami (Departemen Agama RI, 2010), yaitu:

"Dan jika kamu takut tidak akan dapat berlaku adil terhadap (hakhak) perempuan yatim (bilamana kamu mengawininya), maka kawinilah wanita-wanita (lain) yang kamu senangi: dua, tiga atau empat. Kemudian jika kamu takut tidak akan dapat berlaku adil, maka (kawinilah) seorang saja atau budak-budak yang kamu miliki. Yang demikian itu adalah lebih dekat kepada tidak berbuat aniaya."

Chodjim (2007) menambahkan bahwa dalam terjemahan ayat tersebut mewajibkan seorang suami berbuat adil dalam segala hal, termasuk hal batin. Jika seorang suami tidak mampu berbuat adil dalam segala hal, maka seharusnya suami hanya memiliki seorang istri. Fahmie (2007) juga mengemukakan bahwa seorang suami yang melakukan pernikahan poligami harus mampu berlaku adil terhadap istri-istrinya dalam semua aspek, yaitu ekonomi, jatah giliran, kasih sayang, perlindungan, dan memiliki hak yang sama dalam memiliki suami.

\section{Dampak-dampak Poligami}

Setiati (2007) mengemukakan bahwa dalam poligami seringkali terjadi dampak-dampak yang dirasakan suami, baik yang bersifat positif maupun negatif, diantaranya yaitu:

a. Dampak positif berpoligami

1. Terhindar dari maksiat dan zina

2. Memperbanyak keturunan

3. Melindungi para janda dan perawan tua

4. Melatih kesabaran

b. Dampak negatif berpoligami

1. Mendapat tekanan sosial, yang mana masyarakat menganggap buruk pelaku poligami.

2. Tekanan secara psikis

3. Pisah ranjang

\section{Penyandang Tuna Netra}

Kata tunanetra terdiri dari kata tuna dan netra. Tuna artinya rusak sedangkan netra artinya mata. Jadi secara umum artinya rusak penglihatan. Soemantri (2006) mengemukakan 
bahwa tunanetra adalah individu yang indera penglihatannya (kedua-duanya) tidak dapat berfungsi sebagai saluran penerima informasi dalam kegiatan sehari-hari seperti halnya orang awas (normal). Adapun ciri-ciri gangguan penglihatan antara lain:

a. Ketajaman penglihatannya kurang dari ketajaman yang dimiliki orang awas.

b. Terjadi kekeruhan pada lensa mata atau terdapat cairan tertentu.

c. Posisi mata sulit dikendalikan oleh saraf otak.

d. Terjadi kerusakan susunan saraf otak yang berhubungan dengan penglihatan.

WHO (Muhammad, 2008) mendefinisikan bahwa terdapat dua kategori utama dalam masalah penglihatan, yaitu buta dan rabun atau penglihatan yang terbatas (low vision), sebagai berikut:

a. Kebutaan, penglihatan kurang dari 3/60 atau medan penglihatan kurang dari $10 \mathrm{o}$ setelah menerima perawatan atau perbaikan pembiasan (refractive).

b. Rabun ataupun penglihatan terbatas (low vision), penglihatan kurang dari 6/18 sehingga persepsi cahaya atau medan penglihatan kurang dari $10 \mathrm{o}$ sesudah mengalami perawatan ataupun pembaikan pembiasan (refractive). Individu dengan penglihatan terbatas dapat melakukan tugas sehari-hari menggunakan indera penglihatan.

Soemantri (2006) mengemukakan secara ilmiah, ketunanetraan dapat disebabkan oleh faktor internal maupun eksternal. Faktor internal antara lain, yaitu faktor-faktor yang erat hubungannya dengan keadaan bayi selama masih dalam kandungan, kondisi psikis ibu, kekurangan gizi, keracunan obat, dan sebagainya, sedangkan faktor eksternal antara lain disebabkan oleh kecelakaan, mata terkena benda tajam, serta peradangan mata karena penyakit, bakteri, ataupun virus. Muhammad (2008) mengemukakan bahwa terdapat beberapa penyebab kecacatan, yaitu penyakit turunan, komplikasi saat masa kehamilan dan saat melahirkan, Rubela, Sifilis (syphilis), kecelakaan, dan terjangkit penyakit.

\section{Dinamika Psikologis Keluarga Poligami Penyandang Tuna Netra}

Bayu (Hariyanti, 2008) menambahkan bahwa hidup berkeluarga sangat indah, sebab dengan berkeluarga maka orang-orang dapat belajar banyak tentang berbagai hal, mulai dari masalah pendidikan, hubungan sosial antar keluarga, ekonomi, pertahanan, komunikasi, organisasi, dan politik. Orang-orang yang menjalani kehidupan berkeluarga dengan baik dan sukses, maka akan sukses berkiprah di masyarakat bahkan di negara maupun dunia, begitu pula dengan sebaliknya apabila tidak dapat menjalani kehidupan berkeluarga dengan baik dan sukses, maka akan kesulitan berkiprah di masyarakat.

Menjalani kehidupan dalam berpoligami tidaklah mudah, seperti membalikkan telapak tangan. Hidup dalam keluarga poligami, terkadang menimbulkan pro dan kontra dalam masyarakat dan orang-orang yang terlibat, namun hal tersebut dapat diatasi apabila keempat aspek tersebut dapat dijalankan dan dimiliki oleh anggota keluarga poligami.

Setiati (2007) mengartikan bahwa poligami sebagai sistem perkawinan yang dilakukan oleh laki-laki terhadap beberapa perempuan, baik dalam waktu bersamaan maupun tidak. Poligami dapat juga menimbulkan dampak-dampak positif dan negatif. Dampak positif yang ditimbulkan dalam poligami, yaitu dapat terhindar dari perbuatan maksiat dan zina, memperbanyak keturunan, menyelamatkan para janda dan perempuan yang sudah menua,agar dapat masuk surga, melatih kesabaran, cinta terhadap sesama saudari semuslim, terjalinnya tali silaturahmi, dan mengurangi perselingkuhan. Sementara, dampak negatif yang dapat ditimbulkan, yaitu mendapat tekanan sosial di lingkungan masyarakat, tidak dinafkahi, kecemburuan dan persaingan antar para istri berakhir dengan perceraian, tekanan secara psikis, dan kekerasan fisik.

Seseorang yang memiliki fisik normal dan ekonomi yang menunjang tidak saja dapat melakukan poligami, namun seseorang dengan keterbatasan fisik pun dapat melakukan poligami dengan baik dan kehidupan poligaminya pun berjalan lancar dengan semua anggota keluarga, meskipun secara ekonomi sangat rendah.

\section{METODE PENELITIAN \\ 2.1.1 Pendekatan}

Penelitian yang digunakan dalam penelitian ini adalah penelitian kualitatif. Creswell (2010) mengemukakan bahwa penelitian kualitatif merupakan suatu proses penelitian yang memahami masalah-masalah manusia atau sosial dengan menciptakan gambaran 
menyeluruh dan kompleks yang disajikan dengan kata-kata, mendeskripsikan data-data yang telah diperoleh dari para sumber informasi, serta dilakukan dalam latar (setting) yang alamiah atau natural. Penelitian ini bersifat menggambarkan bagaimana bentuk sebuah keluarga poligami dari seorang penyandang tuna netra.

\subsubsection{Unit Analisis}

Unit analisis dalam penelitian ini adalah sebuah keluarga poligami, yang mana suami adalah seorang penyandang tuna netra dan berprofesi sebagai tukang pijat, memiliki empat orang istri yang tinggal dalam satu atap, kecuali istri pertama dan dua orang anak kandung dari subjek. Keluarga yang menjadi unit penelitian ini berdomisili di Kota Makassar.

\subsubsection{Teknik Pengumpulan Data}

Creswell (2010) mengemukakan bahwa salah satu ciri penelitian kualitatif adalah peneliti sebagai instrumen penelitian dan sebagai perencana, pelaksana, dan menganalisis data hingga selesai. Teknik pengumpulan data yang digunakan dalam penelitian ini adalah:

1. Wawancara adalah percakapan dan tanya jawab yang diarahkan untuk mendapatkan informasi tentang orang lain dengan tujuan penjelasan atau pemahaman tentang seseorang dalam hal tertentu. Teknik wawancara yang digunakan pada penelitian ini adalah wawancara tidak terstruktur dimana wawancara mengalir seperti percakapan sehari-hari. Wawancara biasanya berjalan lama dan dilanjutkan pada kesempatan berikut, akan tetapi dalam proses wawancara tetap mengacu pada guide interview yang telah dibuat.

2. Observasi adalah teknik pengumpulan data yang di dalamnya peneliti langsung turun ke lapangan untuk mengamati perilaku dan aktivitas individu-individu di lokasi penelitian.

3. Alat bantu pengumpul data yang digunakan dalam penelitian ini adalah berupa alat perekam (tape recorder). Penggunaan alat bantu ini berfungsi memudahkan peneliti dalam proses pengambilan data dengan sepengetahuan dan persetujuan subjek penelitian.

\subsubsection{Pelaksanaan Penelitian}

Analisis data yang paling sering digunakan dalam studi kasus yaitu analisis yang terdiri dari bagaimana membuat satu uraian (description) dengan terperinci mengenai kasus atau settingnya. Stake (Creswell, 1998) menggunakan 4 format data analisis dan interpretasi dalam studi kasus yaitu:

1. Categorical aggregation, peneliti memulai dengan mencari suatu koleksi kejadian dari data, berharap agar isu relevan akan muncul.

2. Direct interpretation, peneliti mencari sebuah kejadian dan menggambarkan maknanya tanpa mencari multiple kejadian.

3. Pattern, menetapkan pola dan mencari koresponden (correspondence) antara dua atau lebih kategori untuk menetapkan sejumlah kategori kecil.

4. Naturalistic generalization, peneliti mengembangkan naturalistic generalization dari analisis data, kemudian menggeneralisasikan bahwa manusia dapat belajar dari kasus tersebut, baik untuk diri mereka sendri maupun menerapkannya kepada suatu populasi kasus. Peneliti membuat kasus dan dapat dimengerti, sehingga pembaca dapat belajar dari kasus tersebut atau aplikasi pada kasus lain.

\subsection{DISKUSI}

\subsubsection{Hasil Penelitian}

Penelitian ini dilakukan di Makassar terhadap seorang penyandang tuna netra yang melakukan poligami dan memiliki empat orang istri. Peneliti berusaha melakukan eksplorasi lebih mendalam agar dapat menjawab pertanyaan penelitian mengenai dinamika psikologis keluarga poligami penyandang tuna netra. Data dalam penelitian ini diperoleh melalui proses wawancara mendalam (in-depth interview) terhadap keluarga subjek penelitian dengan melibatkan beberapa dari anggota keluarga, selain subjek utama, yaitu istri pertama, istri kedua, istri ketiga, istri keempat, dan dua orang anak kandung dari subjek. Pernyataan-pernyataan subjek penelitian yang dinilai penting, karena berkaitan dengan studi kasus terhadap keluarga yang dipoligami oleh subjek yang diteliti, kemudian dikategorikan dan diklasifikasikan berdasarkan tema tertentu, sehingga membantu peneliti untuk dapat memahami fenomena yang dikaji.

Berdasarkan hasil penelitian, maka dapat disimpulkan bahwa tidak hanya laki-laki yang memiliki fisik normal dapat melakukan 
poligami, namun seorang laki-laki yang memiliki keterbatasan fisik ternyata melakukan poligami hingga empat orang istri dan dapat membina semua keluarganya dengan baik. Tiga dari keempat istrinya tinggal bersama dalam satu atap, dan istri satunya lagi tinggal terpisah dari suaminya namun tetap dalam status suamiistri. Penyandang tuna netra tersebut melakukan poligami, karena merasa bahwa hal tersebut merupakan nasib atau takdirnya. Disamping itu, dia juga berpikir bahwa apa yang telah dilakukannya adalah bersifat menolong, karena istri-istrinya pernah mengalami kekerasan dalam rumah tangganya terdahulu. Selain faktor kekerasan rumah tangga, subjek juga memiliki rasa empati terhadap istri lainnya yang sudah berumur.

Dinamika psikologis yang dialami oleh suami sudah pasti sering dirasakan, baik yang berdampak positif maupun dampak negatif dalam berpoligami. Dampak positif yang dirasakan oleh suami, seperti melindungi dan menolong perempuan yang mengalami kekerasan dalam rumah tangga dan perempuan yang sudah berumur namun belum menikah, agar terhindar dari perbuatan maksiat dan zina, dan dapat terjalinnya tali silaturahmi. Selain itu, dampak negatif yang dirasakan, seperti terjadi kecemburuan diantara para istri dan pelaku poligami dianggap buruk dalam kehidupan masyarakat.

Semenjak berpoligami dan merasakan dampak positif maupun dampak negatif dalam kehidupan poligaminya, subjek condong kearah yang lebih baik dengan memberikan sikap yang positif dalam membina keluarganya. Cara subjek dalam membina keluarganya yaitu dengan selalu mengingatkan kepada semua istri dan anaknya untuk selalu beribadah dan bersabar, sekalipun pernah terjadi konflik diantara para istri dan anak-anaknya. Selain itu dalam hal ekonomi, subjek juga membagi rata pendapatan yang telah didapatkannya kepada istri-istrinya, kecuali istri pertama subjek yang memang sudah tidak dinafkahi lagi sejak subjek menikah dengan istri keduanya.

Pemberian jadwal bergilir kepada istri-istri subjek juga dilakukan secara adil, namun setelah beberapa tahun berlalu subjek hanya mendatangi rumah istri pertama dan keduanya saja tanpa bermalam. Subjek mengaku sekarang ini hanya membagi waktunya dengan mendatangi dua rumah saja untuk bermalam, yaitu di rumah istri ketiga dan keempat.
Sikap positif yang dilakukan oleh subjek dalam membina keluarganya, memberikan dampak yang baik pula terhadap interaksi antar anggota keluarga yang lain. Interaksi antar anggota keluarga lainnya dilakukan dengan cara berkumpul bersama dalam sebuah acara, mempererat tali silaturahim diantara anggota keluarga yang satu dengan yang lainnya. Meskipun pernah terjadi konflik antar keluarga yang satu dengan keluarga lainnya, baik itu istri dengan istri, ibu tiri dengan anak tiri maupun dengan sesama saudara tiri lainnya, namun hal tersebut tidak berlangsung lama dan kembali membaik. Saling memberikan perhatian, menjaga, melindungi, dan memperhatikan antar anggota keluarga yang satu dengan yang lain.

Selain itu, dari interaksi antar anggota keluarga lain yang terjalin dengan baik akan menghasilkan komunikasi yang baik pula diantara para istri, istri dengan anak tiri, dan anak dengan saudara tirinya. Interaksi yang terjalin dengan sangat baik antar anggota keluarga lainnya, dapat menciptakan keluarga yang harmonis. Hal tersebut sangat berpengaruh dalam kehidupan keluarga dan semua anggotaanggota keluarga subjek turut serta dalam menciptakan kerukunan dalam rumah tangga.

\section{PEMBAHASAN}

Dinamika psikologis subjek dalam berpoligami, yaitu:

3.1 Dampak positif dan dampak negatif berpoligami

Melakukan poligami tidak semudah yang dibayangkan. Suami sebisa mungkin bersikap adil dan jujur kepada para istri yang dipoligaminya. Sehingga, dalam poligami seringkali terjadi dampak-dampak yang dirasakan oleh suami, baik yang bersifat positif maupun negatif. Dampak positif yang dirasakan oleh suami, seperti melindungi dan menolong perempuan-perempuan yang mengalami kekerasan dalam rumah tangga, perempuan yang sudah berumur namun belum menikah, lalu agar terhindar dari perbuatan zina, terjalinnya tali silaturahmi, dan sebagainya. Hal tersebut sesuai dengan yang dikemukakan oleh Setiati (2007) bahwa dampak positif berpoligami, yaitu terhindar dari maksiat dan zina, kemudian melindungi para janda dan perawan tua. Faizal (2002) juga menambahkan bahwa dampak positif poligami, meliputi terjalinnya tali silaturahmi dan kesejahteraan pada kaum wanita. 
Selain itu, dampak negatif yang dirasakan oleh suami dalam berpoligami, seperti kecemburuan pada para istri, pisah ranjang, ada dilingkungan sekitar menganggap pelaku poligami tidak baik. Hal tersebut sesuai dengan yang dikemukakan oleh Faizal (2002) bahwa dampak negatif dalam poligami salah satunya dapat menimbulkan kecemburuan dan persaingan antar para istri. Kemudian, Setiati (2007) menambahkan dampak negatif dari poligami, seperti mendapat tekanan sosial, yang mana masyarakat menganggap buruk pelaku poligami dan pisah ranjang.

Suprapto (1990) menjelaskan bahwa ada dampak-dampak psikologis dari poligami, secara psikologis semua istri akan merasa sakit hati, marah, jengkel, kecewa jika melihat suaminya berhubungan dengan perempuan lain. Salah satunya dimana istri merasa dirinya inferior seolah-olah suaminya berbuat demikian lantaran ia tidak mampu memenuhi kepuasan biologisnya. Istri pertama dengan ikhlas dipoligami dan mencarikan seorang wanita untuk suaminya, dikarenakan kondisi istri pertama yang sudah tua dan tidak dapat lagi memenuhi kewajiban sebagai seorang istri.

Selain dampak positif yang dirasakan oleh suami dalam kehidupan poligaminya. Istri yang dipoligami juga turut merasakan keuntungan, Mary, Ben, dan David (Poerwandari, 2003) mengemukakan bahwa poligami memberikan beberapa keuntungan bagi wanita, diantaranya seorang wanita berkesempatan untuk memiliki teman wanita dalam hidup sebagaimana halnya suami. Istri pertama memiliki tiga orang teman hidup, yaitu istri kedua, ketiga, dan keempat. Semua istri saling kompak dan sudah menjadi saudara sendiri. Kemudian, wanita yang dipoligami lebih mendapatkan kebebasan dibandingkan dengan wanita dalam perkawinan monogami. Hal ini disebabkan pada saat tidak sedang digilir oleh suaminya, ia mempunyai waktu pribadi, tidak harus mengurus suami serta dapat mengurus anak dan melakukan hal-hal yang disukainya, seperti pergi ke suatu tempat bersama anak atau sanak saudara tanpa ada pengawasan dari suami.

Mary, Ben, dan David (Poerwandari, 2003) menambahkan bahwa Jika para istri bekerja, maka poligami memungkinkan sedikitnya tiga pemasukan, sehingga bisa mengurangi ketergantungan dan kekhawatiran akan kekurangan. Selama menjadi istri yang dipoligami, istri pertama, kedua, dan keempat berusaha untuk mencari nafkah dengan berusaha bekerja meskipun suami tetap bertanggung jawab untuk menafkahi keempat istrinya. Hal tersebut dilakukan untuk mencari penghasilan tambahan dari istri selain mendapat nafkah dari suami.

3.2 Cara subjek membina keluarga

Fahmie (2007) mengemukakan bahwa seorang suami yang melakukan pernikahan poligami harus mampu berlaku adil terhadap istri-istrinya dalam semua aspek, yaitu ekonomi, jatah giliran, kasih sayang, perlindungan, dan memiliki hak yang sama dalam memiliki suami. Cara subjek dalam mengelola keluarga-keluarganya yaitu dengan selalu mengingatkan kepada semua istri dan anaknya untuk selalu beribadah dan bersabar, sekalipun terjadi konflik diantara istri-istri dan anak-anaknya.

Selain itu, subjek dalam hal ekonomi membagi rata pendapatan yang telah didapatkannya kepada istri-istrinya, kecuali istri pertama subjek yang memang sudah tidak dinafkahi lagi sejak subjek menikah dengan istri keduanya. Pemberian jadwal bergilir kepada istri-istri subjek juga dilakukan secara adil, namun setelah beberapa tahun berlalu subjek hanya mendatangi rumah istri pertama dan keduanya saja tanpa bermalam. Subjek mengaku sekarang ini hanya membagi waktunya dengan mendatangi dua rumah saja untuk bermalam, yaitu di rumah istri ketiga dan keempat.

3.3 Interaksi antar anggota keluarga lainnya

Interaksi antar anggota keluarga lainnya dilakukan dengan cara berkumpul bersama dalam sebuah acara, mempererat tali silaturahmi diantara anggota keluarga yang satu dengan yang lainnya. Meskipun pernah terjadi konflik antar keluarga yang satu dengan keluarga lainnya, baik itu istri dengan istri, ibu tiri dengan anak tiri maupun dengan sesama saudara tiri lainnya, namun hal tersebut tidak berlangsung lama dan kembali membaik. Saling memberikan perhatian, menjaga, melindungi, dan memperhatikan antar anggota keluarga yang satu dengan yang lain. Hal tersebut dikemukakan oleh 
Bayu (Hariyanti, 2008) bahwa tiap keluarga memiliki aturan permainan yang mengatur bagaimana mereka seharusnya merasa dan bertindak yang selanjutnya berkembang sebagai sebuah sistem nilai keluarga.

Selain itu, dari interaksi antar anggota keluarga lain yang terjalin dengan baik akan menghasilkan komunikasi yang baik pula diantara istri-istri, istri dengan anak tiri, dan anak dengan saudara tirinya. Hal tersebut dikemukakan oleh Faizal (2002) yang menyatakan bahwa poligami yang dilakukan dengan terbuka, benar, dan memenuhi kaidah tentang poligami, akan menimbulkan dampak-dampak positif, yaitu terjalinnya tali silaturahmi, kemudian istri yang mengizinkan dengan ikhlas suaminya untuk menikah lagi atau berpoligami dapat mendukung terjalinnya tali silaturahmi dan persaudaraan dengan penuh kehangatan antara suami, istri pertama, istri-istri yang lain, dan keluarga lainnya.

\section{KESIMPULAN DAN SARAN \\ 4.1 Kesimpulan}

Dinamika psikologis dalam berpoligami memiliki beberapa dampak, yaitu:

\subsubsection{Dampak positif}

a. Melindungi dan menolong perempuan yang mengalami kekerasan dalam rumah tangga dan perempuan yang sudah berumur namun belum menikah.

b. Agar terhindar dari perbuatan maksiat dan zina.

c. Terjalinnya tali silaturahmi.

d. Istri memiliki teman dalam bekerja sama mengurus suami.

e. Jika tidak mendapat jatah giliran, istri dapat melakukan hal yang disukainya, seperti pergi ke suatu tempat bersama anak atau sanak saudara.

4.1.2 Dampak negatif

a. Terjadi kecemburuan diantara para istri.

b. Pelaku poligami dianggap buruk dalam lingkungan masyarakat.

c. Istri merasa tidak dapat menjalankan kewajiban sebagai seorang istri.

d. Merasa sakit hati, marah, jengkel, dan kecewa.

\subsubsection{Cara membina keluarga}

Cara membina keluarga yang dilakukan oleh subjek adalah dengan menerapkan ajaran agama, yaitu dengan selalu mengingatkan kepada semua istri dan anaknya untuk taat beribadah dan bersabar agar terhindar dari konflik. Melarang keras kepada semua istri-istri untuk tidak bergosip, ketika sedang bersosialisasi dengan lingkungan sekitarnya. Membagi rata pendapatan yang telah didapatkan kepada istri-istrinya, dalam hal ekonomi. Selain itu, pemberian jadwal bergilir kepada istri-istri yang dilakukan secara adil. Menjaga hubungan baik, tenang, nyaman, dan saling menghargai dengan semua istri-istri, serta anak-anaknya.

\subsubsection{Interaksi antar anggota keluarga lainnya}

Interaksi antar anggota keluarga lainnya dalam penelitian ini dilakukan dengan cara berkumpul bersama dalam sebuah acara, mempererat tali silaturahim diantara anggota keluarga yang satu dengan yang lainnya. Meskipun pernah terjadi konflik antar keluarga yang satu dengan keluarga lainnya, baik itu istri dengan istri, ibu tiri dengan anak tiri maupun dengan sesama saudara tiri lainnya, namun hal tersebut tidak berlangsung lama dan kembali membaik. Saling memberikan perhatian, menjaga, melindungi, dan memperhatikan antar anggota keluarga yang satu dengan yang lain. Terjalin komunikasi yang baik antara istriistri, istri dengan anak tiri, dan anak dengan saudara tirinya.

\subsection{Saran}

1. Bagi masyarakat, agar dapat mengambil sisi positif tentang poligami yang tidak selamanya berdampak negatif bagi orangorang yang mengalaminya.

2. Bagi pihak suami, agar kiranya menjadi pertimbangan bagi kaum laki-laki atau suami yang akan melakukan poligami untuk dapat bersikap adil terhadap istri-istrinya. Mengurangi efek-efek negatif dari poligami dengan cara memperhatikan ketentuanketentuan poligami yang berlaku.

3. Bagi pihak istri, agar kiranya para istri yang dipoligami mampu menciptakan suasana keluarga yang harmonis dan dapat meningkatkan kualitas hubungan dalam rumah tangga.

4. Bagi peneliti selanjutnya, agar kiranya dapat melakukan penelitian kualitatif untuk mengetahui lebih dalam alasan istri pertama mengizinkan suaminya untuk berpoligami. 


\section{DAFTAR PUSTAKA}

As Sadr, S. M. (2003). Saling memberi, saling menerima: Kiat-kiat sukses menjalin hubungan dalam hidup. Jakarta: Pustaka Zahra.

Burhani, R. (2006, 6 Desember). 10\% kasus KDRT di makassar karena poligami. Merdeka (online), (http://www.merdeka.com/pernik/10-kasuskdrt-di-makassar-karena-poligamixz8gvfs.html, diakses tanggal 28 September 2012).

Chodjim, A. (2007). "Benarkah poligami dibenarkan dalam Islam?” Jakarta: Paras.

Creswell, J. W. (1998). Qualitative inquiry and research design: Choosing among five traditions. London: SAGE Publication.

Creswell, J. W. (2010). Research design: Pendekatan kualitatif, kuantitatif, dan mixed. (diterjemahkan oleh Achmad Fawaid). Yogyakarta: Pustaka Pelajar.

Danim, S. (2002). Menjadi peneliti kualitatif. Bandung: Pustaka Setia.

Dickson, A. L. (2007). Pandangan ibu-ibu aisyiyah di malang terhadap poligami. Skripsi (online), (http://www.acicis.murdoch.edu.au/hi/fieldt opics/anne dickson.pdf, diakses pada tanggal 7 November 2012).

Dewi, E. M. P. (2005). Diktat penelitian kualitatif. Fakultas Psikologi: Universitas Negeri Makassar.

Departemen Agama RI. (2010). Al-Qur'an tajwid \& terjemahan. Bandung: CV. Penerbit Diponegoro.

Faizal, N. (2002). Poligami sebagai solusi dan alternatif. Jombang: Lintas Media.

Fahmie, U. A. (2007). Siapa bilang poligami itu sunnah? Depok: Pustaka IIMAN.

Hariyanti. (2008). Konsep poligami dalam hukum islam (Polygamy concept in islam law). Jurnal hukum. Vol. 4, No. 2, Hal. 105-109.

Jones, G. W. (1994). Marriage and divorce in Islamic South East Asia. New York: Oxford University Press, Inc.

LBH. (2005). Bila suami anda melakukan poligami, (online), (http://www.LbhApik.Or.Id/fac - 31.htm, diakses pada tanggal 28 September 2012).

Levinson, D. (1995). Encyclopedia of marriage and the family. New York : Simon \& Schuster Macmillan.
Manurung, B. A. (2008). Perkembangan kemandirian anak tunanetra di sekolah luar biasa bagian a (Studi kasus di SLB-A karya murni johor). Ringkasan skripsi (online), (http:// repository.usu.ac.id/ bitstream/ 123456789/ 31510/.../Chapter \%20II.pdf, diakses pada tanggal 17 Juni 2012).

Muhammad, J. K. A. (2008). Special education for special children: Panduan pendidikan khusus anak-anak dengan ketunaan dan gangguan belajar. Jakarta: Penerbit Hikmah.

Muharani, Q., Hartati, S., \& Dewi, K. S. (2009). Kemandirian pada penyandang low vision (Studi kasus berdasar teori kepribadian Adler). Ringkasan Skripsi (online), (http:///www.eprints.undip.ac.id/11138/1/J URNAL PDF.pdf, diakses pada tanggal 18 Maret 2012).

Nurohmah, L. (2003). Poligami, saatnya melihat realitas. Jurnal perempuan. Vol. 31, hal. 31-45.

Poerwandari, K. (2003). Ilusi poligami. Jurnal perempuan. Vol. 31, hal. 19-29.

Santoso, N. (1996). Kamus pintar bahasa Indonesia. Surabaya: Penerbit Fajar Mulya.

Setiyaji, A. (2006). Aa Gym: mengapa berpoligami? testimoni seorang jurnalis. Jakarta: QultumMedia.

Setiati, E. (2007). Hitam putih poligami: menelaah perkawinan poligami sebagai sebuah fenomena. Jakarta: Cisera Publishing.

Soemantri, S. (2006). Psikologi anak luar biasa. Jakarta: Departemen Pendidikan dan Kebudayaan.

Suprapto, B. (1990). Liku -liku poligami. Yogyakarta : Penerbit Al kausar.

Susanti, D. P., Mufattahah, S., \& Zulkaida, A. (2004). Penerimaan diri pada istri pertama dalam keluarga poligami yang tinggal dalam satu rumah. Jurnal. 